\title{
Effectiveness of Corporate Governance Attributes on Disclosure of Non-Financial Information in Developing Economies
}

\author{
Eric Nzibonera Godfrey Akileng \\ Department of Accounting and Finance, School of Business, College of Business and Management Sciences, \\ Makerere University, P.O. Box 7062, Kampala Uganda
}

\begin{abstract}
The study examines how corporate governance attributes enhance disclosure of non-financial information in developing economies using a case study of companies listed on selected Stock Markets in Sub-Saharan Africa. Corporate governance attributes such as Chief Executive Officer (CEO) non-duality, board size, board composition, audit committee independence, block and director shareholdings are examined while controlling for firm size, profitability and leverage. The study adopts a quantitative research approach where panel data is obtained to carry out a comparative analysis of companies listed on stock markets of South Africa, East Africa and Nigeria. The data is collected from annual reports of each company for a period of four years and is analysed to obtain Random- Effects Multiple regression models. Findings indicate that the effect of CEO Non-duality, board size and having a higher proportion of non-executive directors on boards is significant and positive. Block ownership of shares and directors' shareholdings have a negative effect on disclosure of non-financial information. However, the study does not provide evidence to suggest that Audit committee independence affects non- financial information disclosure. The major contribution of the study is to establish corporate governance attributes that play a vital role in disclosure of non-financial information using a comparative analysis of listed companies in Sub-Saharan Africa. The paper is the first of its kind in developing economies.
\end{abstract}

Keywords: Corporate governance attributes, corporate disclosure, non-financial information.

DOI: $10.7176 / \mathrm{RJFA} / 12-4-02$

Publication date: February $28^{\text {th }} 2021$

\section{0: Introduction}

In accounting and finance literature, corporate disclosure is described as a principle of providing all information about the firm's activities to different user groups in a timely manner to enhance the decision making process (Habibi and Shamsi, 2015). It is an external control mechanism aimed at reducing agency conflicts between internal and external shareholders through provision of valuable information on financial and non-financial results (Omran and Abdelrazik, 2013; Patelli and Prencipe, 2007). The main role of disclosure is to reduce information asymmetry by requiring corporate managers to reveal all the information that affect investment decisions (Meser et al., 2015). According to agency theory, a good corporate governance system is required for transparent corporate information disclosure (Htay, Said and Salman, 2013). A corporate governance system with effective and expert independent board of directors encourage the company to report to stakeholders both financial and non-financial information to guide in the investment decision process (Gunawan, 2019).

Globally, disclosure of non-financial information (also called sustainability reporting, corporate social responsibility reporting and disclosure of environment, social and governance information) has received a lot of attention in accounting and finance literature. Companies are encouraged to report how they handle economic, environmental and social

impact of their activities to global economies so as to answer investors and other interested stakeholders' implicit and explicit questions about corporate operations and their consequences (Marta de la Cuesta Carmen Valor, 2013). Therefore, disclosure of non-financial information generally covers information on governance, environmental and corporate social responsibility activities. Disclosure of governance information addresses elements that are associated with the governance structure of a company such as general corporate information including organization mission and vision, corporate strategy, directors and employees (Gunawan, 2019; Meser et al., 2015).

On the other hand, Corporate social responsibility (CSR) disclosure provides information regarding product and service provision to society and involvement in community projects, including philanthropic activities and environmental matters (Mukhtaruddin, Saftiana and Dwikatama, 2018; Elinda and Nazli, 2012). Corporate social disclosure is also described as disclosure of information about a company's interaction with the society, involvement in community social activities and environmental issues (Parvez and Abdullah, 2011). Reporting CSR information is vital because it is associated with an ample spectrum of relations in the corporation and its various stakeholders as well as the environment (Tariq, Essia and Mohammed, 2019; Vicente et al., 2011). Evidence from both developed and developing countries indicate that corporate social disclosure is receiving a lot of attention from corporations and stakeholders (Parvez and Abdullah, 2011). Thus, strong corporate governance is necessary for sustainable CSR activities (Erna, Riska and Nur, 2018; Shin et al., 2015). The global financial turmoil that 
occurred in the recent past and resulted into social and environmental crises in terms of social implications in form of employee layoffs and financial losses, forces companies to adopt social and governance reporting in a bid to build a better long-term corporate image (Abdifatah, 2013).

\section{0: Theoretical and Hypothesis development \\ 2.1: Agency theory}

The theory proposed by Jensen and Meckling (1976) lays out the basis of the working relationship between the Principals (owners) of corporations and management. The existence of this relationship raises potential conflicts because of different interests and goals that the two parties hold (Gunawan, 2019). For example, owners of these corporations want them to progress significantly while managers who act as agents of the owners are more interested in maximising their welfare and prosperity instead of the prosperity of the entity. To minimise the agency conflicts, corporations are encouraged to strengthen their corporate governance systems to enhance disclosure of information to various interested stakeholders.

\section{2: Stakeholders theory}

Stakeholders have the ability to influence how the company's economic resources are utilised. This is based on the notion that the company should not only get interested in maximising earnings of shareholders but also provide for interests of other stakeholders. Other stakeholders are internal and external parties that can affect the company directly or indirectly such as government, non-governmental organizations and communities around the corporation (Mukhtaruddin, Saftiana and Dwikatama, 2018). The stakeholder theory recognizes the fact that most companies have a large and integrated set of stakeholders to which they have an obligation and responsibility and therefore they should have corporate governance systems tailored towards meeting their specific and diverse requirements (Sweeney and Coughlan, 2008). The implication of the theory is that disclosure of both financial and non-financial information should not only aim at resolving conflicts between corporate management and shareholders but also focus on serving the interests of all stakeholders.

\section{3: Corporate governance and disclosure of non-financial information}

Corporate governance provides mechanisms responsible for enhancing corporate disclosure thus, diffusing agency conflicts based on agency theory perspectives (Samah, Dahawy, Hussainey and Stapleton, 2012). The common tenet in all governance systems is the mechanism to facilitate control of management and achievement of maximum value from company investments (Poh and Grantley, 2013). Therefore, given the role of corporate governance in monitoring company operations, companies with good governance systems are likely to influence management to disclose more corporate information on governance and corporate social responsibility activities. This helps in reducing information gaps between the company and its stakeholders by disclosing all financial and non-financial activities to all interested stakeholders (Roshima et al., 2009). Although research has been widely carried out on corporate governance and corporate social responsibility (CSR) disclosure, relatively less attention has been paid on establishing the link between the two moreover in developing economies (Khan, Muttakin \& Siddiqui, 2012). Since CSR disclosure is influenced by the choices and motives of those involved in decision making process of an organisation, consideration of corporate governance mechanisms, in particular, duality and ownership structure, board size and board composition and establishment of independent audit committees could be important determinants of enhanced information disclosure.

\section{CEO non- duality and disclosure of non-financial information}

Duality is described as a situation where a Chief Executive Officer (CEO) of a company is also holding the role of chairman board of directors (Ezhilarasi and Kabra, 2017; Nauman, 2013). For CEO non-duality, the positions of CEO and chairman board of directors are separate and held by different persons. Separation of the roles help to provide checks and balances on managerial behaviour thus resulting in effective monitoring of managerial opportunistic activities ((Ibrahim, Habbash and Hussainey, 2019; Jing et al., 2008). On the other hand, when the roles of the CEO and chairman board of directors are combined (role duality), the CEO will have the ability to hide more information from other directors, especially non-executive directors and hence disclose less information (Jiz et al., 2014). Role duality concentrates the power of managing company affairs in the hands of an individual which may ultimately reduce the quality and quantity of disclosed information (Sartawi et al., 2014). Role nonduality is likely to enhance the company's ability to control managerial activities which ultimately leads to increased disclosure of both financial and non-financial information. Based on literature review, it is hypothesised as:

$H_{1:}$ Separation of roles of CEO and chairman board of directors (CEO non-duality) has a positive significant effect on disclosure of non-financial information by listed companies in developing economies. 


\section{Board size and disclosure of non-financial information}

Board size refers to the total number of members on the board of directors. A corporate board is one of the important attributes of corporate governance with a duty of overseeing the conduct and management of company operations. It helps to play the vital function of monitoring and controlling actions of corporate managers. Board size is a vital corporate governance attribute (Nandi and Ghosh, 2012) and is expected to have a positive effect on disclosure of corporate information (Akhtaruddin et al., 2009). The implication is that large boards have directors with diverse professional expertise, skills and experience and are therefore more effective in enhancing corporate disclosure (Stefanescu, 2013). Large boards are also not easily influenced by management (Naseem, Riaz, Rehman, Ikram and Malik, 2017). However, Ujunwa (2012) reports that a large board size has been criticized for increasing cost and boardroom squabbles and therefore is not effective in exerting influence on the disclosure of corporate information. This view is supported by Stefanescu (2013) who assert that large boards are less effective in reducing agency conflicts compared to smaller ones because they are slow in reacting to decisions that require immediate action. Contrary to this, Ntim et al. (2012) states that; there is a positive relationship between board size and disclosure of governance information. From the agency theory perspective, it is believed that board size has a positive significant effect on disclosure of corporate information. Hence, the following hypothesis is stated:

$H_{1:}$ Board size has a positive significant effect on disclosure of non-financial information by listed companies in developing economies.

\section{Board independence and disclosure of non-financial information.}

Board independence describes the extent to which the board of directors of a company is composed with both executive and non-executive directors. The focus is on the ratio of non-executive directors to the total number of directors. The higher the ratio, the more independent the board is in monitoring and controlling the activities of corporate managers (Aboagye, Bedi and Ossei, 2012). This is because corporate boards are regarded as internal control mechanisms intended to carry out decisions on behalf of shareholders and other external stakeholders to ensure that management behaviour is consistent with shareholders' interests (Jing et al., 2008). They have a fiduciary obligation to shareholders and are responsible for providing corporate strategic direction and monitoring (Emma and Juan, 2010). Based on the agency theory, a higher proportion of independent non-executive directors on the board enhances the independence of boards to make decisions and encourages management to disclose all material information (Naseem et al. 2017; Htay et al., 2012). The presence of non-executive directors on the board could control the agency problem and reduce information asymmetry between management and shareholders through providing more corporate information (Sartawi, Hindawi, Bsoul and Ali, 2014). According to Roshima, Yeserrie and Hasinah (2009), Independent non-executive directors play a vital role in enhancing corporate image and act as a monitoring tool in ensuring that a company is properly managed. The agency theory suggests that a greater proportion of non-executive directors is necessary to monitor any self- interested actions by corporate executive managers and to minimise agency costs. Corporate boards with a large proportion of non-executive directors are more effective in monitoring managerial opportunism and therefore important in ensuring full disclosure of both financial and non-financial information. Based on the agency theory and literature review, it is hypothesised as:

$H_{1}$ : Board independence has a positive significant effect on disclosure of non-financial information by listed companies in developing economies.

\section{Block ownership structure and disclosure of non-financial information.}

For this study, block (concentrated) ownership structure is described as ownership of 5\% or more of the company's total shareholding. Block ownership determines the level of corporate disclosure because majority shareholders have the ability to influence and acquire information from informal channels (Sartawi, 2014) which limits the need for general public corporate disclosure. If share ownership is not block, then it is less concentrated or widely spread. With a wide spread ownership structure, corporate disclosure is used as a control and monitoring tool for reducing agency conflicts between shareholders and managers (Jensen and Meckling, 1976). Furthermore, Poh and Grantley (2013) assert that firms with a concentrated ownership structure disclose less information and those with diffused ownership disclose more information to reduce agency costs and information asymmetry in line with the agency theory. However, according to Adawi and Rwegasira (2012), controlling shareholders in a company normally have a strong incentive to monitor management actions and therefore, concentrated share ownership is an influential attribute of corporate governance that ultimately results into increase in corporate information disclosure. Contrary to this view, the potential for agency conflicts is higher in companies with less block ownership because of conflicting interests between contracting parties (Ferreira et al., 2012). Such companies have a large number of shareholders that are not directly involved in the day-to-day operations and management of the company and consequently, agency costs may arise due to information asymmetry between shareholders and management. Based on the agency theory and the need to mitigate the agency conflicts between shareholders and corporate managers, it is hypothesised that: 
$H_{1}$ : Block ownership of shares has a negative significant effect on disclosure of non-financial information by listed companies in developing economies.

\section{Director ownership and disclosure of non-financial information}

Director ownership describes the proportion of shareholding by company directors and senior managers. It is an important factor in corporate governance and disclosure studies because it is believed that directors who hold substantial proportions of shares in corporate entities may not wish to disclose information to the general public (Htay, 2012). This is because directors are able to access the information internally and could also use their discretionary powers to spend corporate resources in a manner that serves their own interests at the expense of shareholders. However, this view is contrasted by Laivi (2009) who assert that if senior directors have shareholdings in the company, then managerial interests in the company will be expected to be similar to those of other shareholders and therefore corporate managers will have less interests in hiding information from investors. Ultimately, this enhances disclosure of corporate information.

According to Nazli (2007), companies with a high proportion of director shareholding may not heavily invest in socially responsible activities, hence disclosure of non-financial information such as information on corporate social activities is limited. The agency theory discourages increased managerial share ownership if companies are to effectively disclose information to all interested stakeholders. A reduction in managerial (director) ownership of shares implies that a company has more external stakeholders who put pressure on corporate managers to disclose more information than what is demanded by laws or regulations (Donnelly and Mulcahy, 2008). Therefore, it is expected that companies with a high proportion of director ownership of shares disclose less information to the public. Based on these assertions, it is hypothesized as:

$H_{l}$ : Director Ownership of shares has a negative significant effect on disclosure of non-financial information by listed companies in developing economies.

\section{Audit committee independence and disclosure of non-financial information}

Audit committees are monitoring mechanisms established in high agency cost firms to improve the quality of information flow between principals and agents and play a complementary role in enhancing information disclosure (Samaha et al., 2012). Audit committee is part of the corporate governance structure that helps in overcoming agency related conflicts in the company (Odoemelam and Okafor, 2018). The monitoring of corporate activities by audit committees is enhanced if the independence of the committee is increased by the appointment of more non-executive directors (Nurul and Sherliza, 2011). Nandi and Ghosh (2012) suggest that effective and independent audit committees enhance financial reporting and disclosure quality by fulfilling various responsibilities such as the implementation of appropriate accounting policies, review of accounts and financial statements and to ensure that the internal controls in place are sufficient.

According to Won et al. (2011), companies with independent audit committees are less likely to manipulate earnings and more likely to voluntarily disclose all financial and non-financial information. However, mere presence of audit committees may not necessarily translate into better financial reporting quality. Nurul and Sherliza (2011) further assert that the role of an independent audit committee is to safeguard an organization through its authority to question corporate management regarding the way financial reporting and disclosure responsibilities are handled as well as making sure that where necessary, corrective actions are taken. The agency theory suggests that the independent members of the audit committee can help shareholders to monitor the activities of corporate managers and hence increase the effectiveness and efficiency of corporate boards in monitoring financial reporting processes of the company (Aboagye et al., 2012). Therefore, the presence of nonexecutive members on audit committees is likely to help in the monitoring of managerial activities and ultimately enhance corporate information disclosure. On the basis of this, it is hypothesized that:

$H_{l}$ : Audit committee independence has a positive significant effect on disclosure of non-financial information by listed companies in developing economies.

\section{Control variables}

To reduce the impact of other variables that could explain the relationship between corporate governance and information disclosure, three control variables were included in the regression models. These are: firm size, profitability and leverage. They were identified through empirical studies by Rouf(2011); Akhtaruddin et al. (2009) and Nandi and Ghosh (2012) as the main control variables that influence disclosure of both financial and nonfinancial information.

Firm size has consistently been found to be significantly and positively associated with corporate disclosure level and therefore large firms are expected to follow better corporate disclosure practices (Nandi and Ghosh, 2012). Managers of large companies are more likely to realize benefits of better disclosure while small companies are more likely to feel that full information disclosure could endanger their competitive position (Rouf, 2011). In addition, large firms tend to disclose more information because they are more exposed to public scrutiny and also 
possess sufficient resources for collecting, analysing and presenting extensive amounts of data at minimal costs (Khalid, 2006). For leverage, Managers of highly leveraged companies are expected to disclose more information to enable creditors evaluate the companies' ability to meet their financial obligations. Accordingly, agency theory posits that higher monitoring costs would be incurred by firms that are highly leveraged and to reduce this, firms are expected to disclose more information (Laivi, 2009; Desoky and Mousa, 2012; and Akhtaruddin and Hasnah, 2010). For profitability, Nandi and Ghosh (2012) assert that profitable firms disclose more information in annual reports to differentiate them from poor performers. Managers of profitable companies are motivated to disclose more financial information to support the continuance of their positions and remuneration and to signal institutional confidence (Rouf, 2011). It is also believed that while corporate managers are usually reluctant to give information about non-profitable companies, profitable companies will tend to disclose more information to show that they have achieved better performance, so as to attract more investors (Oluwaremi, 2014).

\section{0: Methodology:}

\section{Research Design and approach}

The study used a quantitative approach where panel data was obtained and analysed to examine the effect of selected corporate governance attributes on disclosure of corporate non-financial information. The panel data was used to carry out a comparative analysis of the stock market data and corporate governance information of listed firms in South Africa, East Africa and Nigeria. Panel data is preferred in quantitative analysis over cross-sectional data because it combines time series of cross section observations, which gives more informative data, less collinearity among variables, more degrees of freedom and more efficiency (Gujarati, 2003).

\section{Sample and sources of data}

Data was obtained from annual reports of 146 non-financial firms with all the required information on corporate governance and disclosure, from selected Securities Exchanges in Sub-Saharan Africa, for the period 2013-2016. The choice of the period is justified because; for South African listed firms, this was a period during which the King III Report that came into effect in 2010, was being implemented. The Report outlines the application of several corporate governance attributes which were the focus of this study. The period was also when most companies globally were recovering from 2007-2010 financial crises which also affected some of the developing economies like Nigeria. It was expected that by this study period (2013-2016), companies would have strengthened corporate governance systems to monitor operations and improve disclosure of all corporate information in order to boost investments and economic growth. The annual reports were for 95 companies listed on the Johannesburg Securities Exchange in South Africa, 25 companies listed on the Nigeria Stock Exchange in West Africa and 26 companies listed on the Nairobi and Uganda Securities Exchanges in East Africa. Financial firms such as banks and insurance companies were excluded from the study because they are specialised in nature with a tight regulatory environment and are normally subjected to different disclosure requirements and accounting principles (Abdifatah, 2013). The sample also excluded firms whose corporate governance data and information on corporate disclosure could not be obtained from the company websites, corporate governance reports and annual reports for the full period of the study. Most annual reports of companies listed on the selected Securities Exchanges in SubSaharan Africa are available from the BFA McGregor and Bloomberg Databases. These were the major sources of data for this study.

\section{Measurement of variables of study}

The study used selected corporate governance attributes as independent variables; firm size, leverage and profitability as control variables, and disclosure of non-financial information as the dependent variable. Corporate governance variables used in this study include: CEO non-duality, board size, board composition, composition of audit committees and ownership structure (Block share ownership and director ownership). Based on existing studies by Nandi and Ghosh, (2012); Rouf, (2011); Habbash and Hussainey, (2019); Chakraborty,(2010) and Barako et al. (2006), measurements of variables were carried out as per the information summarised in the table below:

Table 1. Measurements of corporate governance attributes and control variables

\begin{tabular}{|l|l|}
\hline Independent and control variable & Measurement \\
\hline CEO non-duality & $\begin{array}{l}\text { Dichotomous: 1 indicating separation of roles of CEO and Board } \\
\text { chairman and 0 otherwise (Ibrahim, Habbash and Hussainey, 2019) }\end{array}$ \\
\hline Board size & Total number of directors on the board. \\
\hline Board composition & $\begin{array}{l}\text { Ratio of non-executive directors to total number of directors on the board } \\
\text { (Ibrahim, Habbash and Hussainey, 2019) . }\end{array}$ \\
\hline Composition of audit committee & $\begin{array}{l}\text { Ratio of non-executive directors to total number of directors on the audit } \\
\text { committee. }\end{array}$ \\
\hline
\end{tabular}




\begin{tabular}{|l|l|}
\hline Independent and control variable & Measurement \\
\hline $\begin{array}{l}\text { Concentrated ( Block) share } \\
\text { ownership }\end{array}$ & $\begin{array}{l}\text { Percentage of shares held by shareholders with at least 5\% of the total } \\
\text { company shareholdings (Ntim et al., 2012). }\end{array}$ \\
\hline Director ownership of shares & Proportion of shares held by directors (Nazli,2007). \\
\hline Firm size & Natural logarithm of total assets (Arosa et al., 2010). \\
\hline Leverage & $\begin{array}{l}\text { Debt ratio defined as a ratio of total debt to total assets (Kowalewski et } \\
\text { al., 2009). }\end{array}$ \\
\hline Profitability & $\begin{array}{l}\text { Measured by return on assets computed as the ratio of earnings before } \\
\text { interest and tax to total assets (Chakraborty, 2010). }\end{array}$ \\
\hline
\end{tabular}

Source: Literature review.

For disclosure of non-financial information, a self-constructed disclosure index was developed to measure the level of disclosure. The index included 40 selected items on non-financial information which all listed companies are supposed to disclose in their annual reports. The items covered information on strategy, governance and corporate social responsibility. This approach of selection of items to include in a disclosure index is supported by Elsayed and Hoque (2010) who stress that the existing literature on disclosure of corporate information does not provide a number of alternatives for measuring corporate disclosure other than use of the disclosure index. Furthermore, Barako et al. (2006) assert that there is no general theory that provides guidance on selection of items to measure the level of corporate disclosure because disclosure by its nature is an abstract construct with no measurable characteristics that can be used to determine its quality. To minimise subjectivity in selection of items, the disclosure index constructed was given to three selected professional experts. They all read and edited the disclosure index that had been developed and later remained with 40 items in the final disclosure index.

\section{Estimating and scoring the disclosure index}

The disclosure index was estimated by scoring disclosure items in the company annual reports. According to Akhtaruddin et al. (2009), researchers can use two methods for scoring disclosure items in the disclosure index used to determine the level of corporate disclosure. That is, use of weighted and un-weighted approaches. The weighted approach puts emphasis on the relative importance of the different disclosed items to the users of annual company reports while the un-weighted disclosure index assumes that each item disclosed is equally important (Nandi and Ghosh, 2012). According to Barakat et al. (2015), with the un-weighted approach of scoring the disclosure items, attention is given to all users of company reports rather than a specific particular user group and therefore all the items disclosed have equal importance. Therefore, the study adopted the un-weighted approach of scoring disclosure items because all items in the disclosure index were regarded to have equal importance. With this approach, a dichotomous procedure is used where an item is scored one if it is disclosed and zero otherwise. The index is then obtained as a ratio of total disclosure to total possible disclosure.

\section{The Research Model}

The study used multiple regression analysis where Random-Effects regression models were used to obtain results on the effect of corporate governance attributes on disclosure of non- financial information. The models describe the relationship between independent, dependent and control variables of the study. The choice of the RandomEffects model in regression analysis was appropriate for this study because of presence of dummy and time invariant variables. This is supported by Gujarati and Porter (2009) who state that use of random effects model helps to include in the analysis relevant explanatory variables that do not change overtime and possibly others that do change overtime but have the same value for all cross-sectional units. The dummy variable was CEO nonduality, where the score was 1 for the separation of roles of CEO from those of the board chairperson and zero otherwise. The time invariant explanatory variables were board size, board composition and composition of the audit committees which may not necessarily change from one year to another. The independent variables included in the research model are: CEO non-duality (CEO), board size (BS), board composition (BC), Independence of audit committees (IAC), block share ownership (BO) and director share ownership (DO) while control variables are: firm size, leverage and profitability. The dependent variable was disclosure of non-financial information.

Based on the theoretical and existing empirical studies such as those carried out by Samaha et al. (2012) and Khan, Muttakin and Siddiqui (2012), a modified model that put into consideration availability of data was developed using the following econometric equation.

$$
\begin{aligned}
& C D_{i t}=\alpha O_{i t}+\alpha_{1} C E O_{i t}+\alpha_{2} B S_{i t}+\alpha_{3} B C_{i t}+\alpha_{4} I A C_{i t}+\alpha_{5} B O_{i t}+\alpha_{6} D O_{i t} \\
& +\alpha_{7} F S_{i t}+\alpha_{8} L e v_{i t}+\alpha_{9} P_{i t}+e i+u_{t} .
\end{aligned}
$$

Where CD: Corporate disclosure of non-financial information; $\alpha_{\mathrm{O}}$ : Intercept term; $\mathrm{e}_{\mathrm{i}}$ and $\mathrm{u}_{\mathrm{t}}$ : Between and within entity error terms; $\alpha_{1} \ldots \ldots \alpha_{9}$ : Slope coefficients. 
4.0: Results of correlation analysis.

Table 2. Spearman's correlation for listed firms in South Africa

\begin{tabular}{|c|c|c|c|c|c|c|c|c|c|}
\hline Variables & $\mathrm{BS}$ & $\mathrm{BC}$ & IAC & Block & Director & Lev & Prof & Non- fin & 1nfirm \\
\hline BS & 1 & & & & & & & & \\
\hline $\mathrm{BC}$ & $0.2172 * * *$ & 1 & & & & & & & \\
\hline IAC & 0.0821 & 0.017 & 1 & & & & & & \\
\hline Block & -0.0647 & $0.1501 * * *$ & -0.0125 & 1 & & & & & \\
\hline Director & $-0,1972$ & -0.3445 & -0.0856 & -0.2483 & 1 & & & & \\
\hline Lev & 0.0197 & -0.0796 & -0.0822 & -0.2077 & 0.0378 & 1 & & & \\
\hline Prof & $0.1371^{* * *}$ & 0.0844 & 0.025 & -0.1115 & -0.0705 & -0.142 & 1 & & \\
\hline Non- fin & $0.1208 * *$ & $0.1038^{* *}$ & 0.0201 & $-0.2308 * *$ & -0.1801 & $0.1230 * *$ & $0.1232 * *$ & 1 & \\
\hline 1nfirm & $0.5713^{* * *}$ & $0.3597 * * *$ & 0.0521 & -0.0783 & -0.4111 & $0.2249 * * *$ & 0.0698 & $0,1758^{* * *}$ & 1 \\
\hline $\begin{array}{l}* * * \text {. Corre } \\
* * \text {. Correla } \\
* \text {. Correlat }\end{array}$ & $\begin{array}{l}\text { on significan } \\
\text { n significant } \\
\text { significant a }\end{array}$ & $\begin{array}{l}\text { it } 0,01 \text { level ( } \\
0,05 \text { level (2 } \\
, 1 \text { level (2-ta }\end{array}$ & $\begin{array}{l}\text { tailed) } \\
\text { iiled) } \\
\text { d) }\end{array}$ & & & & & & \\
\hline
\end{tabular}

Source: Primary data, Where: BS represents total number of directors on the board ; BC: Proportion of nonexecutive directors to total number of directors on the board; IAC: Proportion of non-executive directors to total number of directors on the audit committee; Block: proportion of shares held by shareholders with at least $5 \%$ of total company shareholding; Director: proportion of shares held by directors; Infirm: Natural logarithm of book value of total assets; Lev: Ratio of total debt to total assets; Prof: Ratio of earnings before interest and tax to total assets; Non-fin: disclosure of non-financial information.

Table 3: Spearman's correlation for listed firms in East Africa

\begin{tabular}{|c|c|c|c|c|c|c|c|c|c|}
\hline Variables & $\mathrm{BS}$ & $\mathrm{BC}$ & IAC & Block & Director & Lev & Prof & Non- fin & 1nfirm \\
\hline BS & 1 & & & & & & & & \\
\hline $\mathrm{BC}$ & $0.4039 * * *$ & 1 & & & & & & & \\
\hline IAC & 0.1578 & $0,3131 * * *$ & 1 & & & & & & \\
\hline Block & -0.1647 & $-0,1771$ & -0.19 & 1 & & & & & \\
\hline Director & 0.153 & 0,1961 & 0.2698 & -0.4747 & 1 & & & & \\
\hline Lev & -0.0685 & $-0,1382$ & 0.0204 & -0.1466 & -0.1639 & 1 & & & \\
\hline Prof & 0.1579 & $-0,1886$ & -0.0229 & 0.0352 & 0.0142 & -0.3104 & 1 & & \\
\hline Non- fin & $0.4254 * * *$ & $0,2274^{* *}$ & 0.1085 & -0.1097 & 0.0938 & 0.0566 & $0.1723^{* *}$ & 1 & \\
\hline 1nfirm & $0.4759 * * *$ & $-0,0066$ & 0.045 & 0.0438 & 0.0545 & $0.1902 *$ & $0.1754^{*}$ & $0.501 * * *$ & 1 \\
\hline \multicolumn{10}{|c|}{$\begin{array}{l}\text { ***. Correlation significant at } 0.01 \text { level (2-tailed) } \\
* * \text {. Correlation significant at } 0.05 \text { level (2-tailed) } \\
* \text { Correlation sionificant at } 0.1 \text { level (2-tailed) }\end{array}$} \\
\hline
\end{tabular}

Source: Primary data, Where: BS represents total number of directors on the board ; BC: Proportion of nonexecutive directors to total number of directors on the board; IAC: Proportion of non-executive directors to total number of directors on the audit committee; Block: proportion of shares held by shareholders with at least $5 \%$ of total company shareholding; Director: proportion of shares held by directors; Infirm: Natural logarithm of book value of total assets; Lev: Ratio of total debt to total assets; Prof: Ratio of earnings before interest and tax to total assets; Non-fin: disclosure of non-financial information. 
Table 4: Spearman's correlation for listed firms in Nigeria

\begin{tabular}{|c|c|c|c|c|c|c|c|c|c|}
\hline Variables & $\mathrm{BS}$ & $\mathrm{BC}$ & IAC & Block & Director & Lev & Prof & Non- fin & 1nfirm \\
\hline $\mathrm{BS}$ & 1 & & & & & & & & \\
\hline $\mathrm{BC}$ & -0.1115 & 1 & & & & & & & \\
\hline IAC & -0.1502 & $0.4775^{* * *}$ & 1 & & & & & & \\
\hline Block & 0.0444 & -0.2869 & -0.2438 & 1 & & & & & \\
\hline Director & -0.2263 & $0.2491 * *$ & $0.3032^{* * *}$ & -0.3012 & 1 & & & & \\
\hline Lev & -0.0822 & 0.0244 & -0.1462 & -0.0856 & -0.2247 & 1 & & & \\
\hline Prof & $0.3137 * * *$ & $0.2204 * *$ & $0.2642 * * *$ & -0.2004 & -0.0397 & -0.297 & 1 & & \\
\hline Non- fin & $0.214^{* *}$ & 0.2165 & -0.2063 & $-0.1319 * *$ & -0.2478 & -0.0229 & 0.1503 & 1 & \\
\hline 1nfirm & $0.5823^{* * *}$ & -0.1207 & -0.2809 & 0.1542 & -0.2217 & 0.1426 & 0.1463 & $0.3183^{* * *}$ & 1 \\
\hline
\end{tabular}

Source: Primary data, Where: BS represents total number of directors on the board ; BC: Proportion of nonexecutive directors to total number of directors on the board; IAC: Proportion of non-executive directors to total number of directors on the audit committee; Block: proportion of shares held by shareholders with at least $5 \%$ of total company shareholding; Director: proportion of shares held by directors; Infirm: Natural logarithm of book value of total assets; Lev: Ratio of total debt to total assets; Prof: Ratio of earnings before interest and tax to total assets; Non-fin: disclosure of non-financial information.

Findings of Spearman's correlation coefficients in tables 2, 3 and 4 show that board size and board composition have a positive and significant relationship with disclosure of non-financial information. This implies that as board size and the proportion of non-executive directors on corporate boards increase, disclosure of nonfinancial information also increases. The results are consistent with Naseem et al. (2017); Htay et al. (2012); Roshima Yeserrie and Hasinah (2009) and Nandi and Gosh (2012) who argue that board size and a high proportion of non-executive directors on the board of directors enhance independence in corporate decision making and encourage management to disclose information to corporate stakeholders. The relationship between the predictor variables (director shareholding and independence of audit committee) and the dependent variable (disclosure of non-financial information) was not statistically significant. The study also finds a significant negative relationship between block share ownership and disclosure of non-financial information for listed firms in South Africa and Nigeria. This implies that as the block share ownership increases, disclosure of non-financial information reduces. The findings are supported by Sartawi (2014), who state that concentrated share ownership limits the need for the general public disclosure of corporate information because the information can be accessed by these block shareholders through the informational company channels of communication. The study did not find any significant relationship between block share ownership and disclosure of non-financial information for listed firms in East Africa.

\section{0: Discussion and conclusion of results of regression analysis}

The panel data analysis was carried out using data for a period of four years from 2013 to 2016 to carryout a comparative analysis for listed companies in South Africa, East Africa and Nigeria. The year 2013 is not indicated in results of regression analysis given in tables 5, 6 and 7 because it was used as a reference point (base year) during analysis. 
Table 5: Multiple Regression analysis (One-tailed test) for disclosure of non-financial Information from listed firms in South Africa

\begin{tabular}{|c|c|c|c|c|}
\hline $\begin{array}{l}\text { Random - effect ML } \\
\text { regression }\end{array}$ & & & Number of observations $=380$ & \\
\hline Group variable: id & & & Number of groups $=95$ & \\
\hline Random effects $\mathrm{u}$ i -Gaussian & & & $\begin{array}{l}\text { observations per group: } \\
\min =4 ; \max =4\end{array}$ & \\
\hline Log likelihood $=454.0366$ & & & LR $\operatorname{chi} 2(13)=67.4$ & \\
\hline & & & Prob $>$ chi $2=0.0000$ & \\
\hline Non-financial information & Coefficient & $\begin{array}{l}\text { Standard } \\
\text { Error }\end{array}$ & T stat & p value \\
\hline Year & & & & \\
\hline 2014 & 0.0293 & 0.00949 & 3.09 & 0.001 \\
\hline 2015 & 0.0291 & 0.00955 & 3.04 & 0.010 \\
\hline 2016 & -0.0251 & 0.00984 & -2.56 & 0.0055 \\
\hline CEO Non-duality & 0.0478 & 0.0326 & 1.47 & 0.0715 \\
\hline Board size & -0.0017 & 0.0021 & -0.81 & 0.208 \\
\hline Board composition & 0.0927 & 0.0502 & 1.85 & 0.0325 \\
\hline $\begin{array}{l}\text { Audit committee } \\
\text { independence }\end{array}$ & -0.1076 & 0.0877 & -1.23 & 0.110 \\
\hline Block ownership & -0.0695 & 0.0245 & -2.84 & 0.0025 \\
\hline Director ownership & -0.0892 & 0.0314 & -2.84 & 0.0025 \\
\hline Leverage & 0.0395 & 0.0299 & 1.32 & 0.093 \\
\hline Profitability & 0.0674 & 0.0444 & 1.52 & 0.0645 \\
\hline Natural log. Firm size & 0.0037 & 0.0038 & 0.97 & 0.1665 \\
\hline Constant & 0.778 & 0.1225 & 6.35 & 0.000 \\
\hline /sigma_u & 0.0422 & 0.005 & & \\
\hline /sigma_e & 0.0647 & 0.0027 & & \\
\hline Rho & 0.2983 & 0.0567 & & \\
\hline \multicolumn{4}{|c|}{ likelihood-ratio test of sigma_u $=0$ : chibar2 $(01)=38.77$ prob $>=$ chibar2 $=0.000$} & \\
\hline
\end{tabular}

Source: Primary data, one-tailed test, where: Non-financial is disclosure of information of non-financial information; other variables are defined in table 2 
Table 6. Multiple regression analysis (one-tailed test) for disclosure of non-financial information from listed firms in Nigeria.

\begin{tabular}{|c|c|c|c|c|}
\hline $\begin{array}{l}\text { Random - effect ML } \\
\text { regression }\end{array}$ & & & Number of observations $=100$ & \\
\hline Group variable: id & & & Number of groups $=25$ & \\
\hline $\begin{array}{l}\text { Random effects u_i - } \\
\text { Gaussian }\end{array}$ & & & $\begin{array}{l}\text { Observations per group: } \quad \text { Min }=4 ; \\
\operatorname{Max}=4\end{array}$ & \\
\hline \multirow[t]{2}{*}{ Log likelihood $=96.81345$} & & & LR $\operatorname{chi} 2(12) \quad=15.95$ & \\
\hline & & & Prob $>$ chi $2=0.1937$ & \\
\hline $\begin{array}{l}\text { Non-financial } \\
\text { information }\end{array}$ & Coefficient & $\begin{array}{l}\text { Standard } \\
\text { Error }\end{array}$ & T stat & p value \\
\hline \multicolumn{5}{|l|}{ Year } \\
\hline 2014 & -0.01269 & 0.023518 & -0.540 & 0.2945 \\
\hline 2015 & -0.002397 & 0.023995 & -0.100 & 0.460 \\
\hline 2016 & -0.007759 & 0.026251 & -0.300 & 0.384 \\
\hline CEO Non-duality & -0.0893 & 0.04866 & -1.83 & $\mathbf{0 . 0 3 3 5}$ \\
\hline Board size & 0.0163 & 0.00733 & 2.23 & 0.0130 \\
\hline Board composition & -0.0664 & 0.1136 & -0.58 & 0.2795 \\
\hline $\begin{array}{l}\text { Audit committee } \\
\text { independence }\end{array}$ & -0.03215 & 0.1152 & -0.28 & 0.3900 \\
\hline Block ownership & 0.03309 & 0.07944 & 0.42 & 0.3385 \\
\hline Director ownership & 0.21055 & 0.1644 & 1.28 & 0.100 \\
\hline Natural log. Firm size & 0.00072 & 0.00722 & 0.1 & 4605 \\
\hline Leverage & 0.06941 & 0.0818 & 0.85 & 0.198 \\
\hline Profitability & 0.1269 & 0.1112 & 1.14 & 0.127 \\
\hline Constant & 0.5846 & 0.21204 & 2.76 & 0.003 \\
\hline /sigma_u & 0.06087 & 0.0157 & & \\
\hline /sigma_e & 0.07892 & 0.00698 & & \\
\hline Rho & 0.373 & 0.14113 & & \\
\hline likelihood-ratio test of sigm & $\mathrm{u}=0$ : chiba & $01)=9.42$ & $\mathrm{~b}>=$ chibar2 $=0.001$ & \\
\hline
\end{tabular}

Source: Primary data, one-tailed test, where: Non-financial represents disclosure of non-financial information; other variables are defined in table 2 
Table 7: Multiple Regression analysis (One-tailed test) for disclosure of non-financial information using data from East Africa.

\begin{tabular}{|c|c|c|c|c|}
\hline $\begin{array}{l}\text { Random - effect ML } \\
\text { regression }\end{array}$ & & & Number of observations $=104$ & \\
\hline Group variable: id & & & Number of groups $=26$ & \\
\hline $\begin{array}{l}\text { Random effects u_i - } \\
\text { Gaussian }\end{array}$ & & & $\begin{array}{l}\text { observations per group: } \quad \text { Min }= \\
4 ; \operatorname{Max}=4\end{array}$ & \\
\hline Log likelihood $=99.7425$ & & & LR $\operatorname{chi} 2(12)=18.35$ & \\
\hline & & & Prob $>$ chi2 $=0.1005$ & \\
\hline $\begin{array}{l}\text { Non-Financial } \\
\text { information }\end{array}$ & Coefficient & $\begin{array}{l}\text { Standard } \\
\text { Error }\end{array}$ & T stat & p value \\
\hline Year & & & & \\
\hline 2014 & -0.01071 & 0.02294 & -0.47 & 0.3205 \\
\hline 2015 & -0.00315 & 0.02263 & -0.14 & 0.4445 \\
\hline 2016 & -0.03243 & 0.02312 & -1.4 & 0.0805 \\
\hline CEO Non duality & 0.1178 & 0.07711 & $\mathbf{1 . 5 3}$ & 0.063 \\
\hline Board size & 0.00344 & 0.0062 & 0.56 & 0.2895 \\
\hline Board composition & 0.26375 & 0.15424 & 1.71 & 0.0415 \\
\hline $\begin{array}{l}\text { Audit committee } \\
\text { composition }\end{array}$ & -0.03614 & 0.11608 & -0.31 & 0.378 \\
\hline Block ownership & -0.05284 & 0.07844 & -0.67 & 0.2505 \\
\hline Director ownership & 0.08158 & 0.16353 & 0.5 & 0.309 \\
\hline Leverage & 0.07752 & 0.07416 & 1.05 & 0.148 \\
\hline Profitability & 0.14689 & 0.13242 & 1.11 & 0.1335 \\
\hline Natural log. Firm size & 0.02234 & 0.00987 & 2.26 & 0.012 \\
\hline Constant & -0.15603 & 0.25756 & -0.61 & 0.2725 \\
\hline /sigma_u & 0.05685 & 0.01457 & & \\
\hline /sigma_e & 0.08092 & 0.00687 & & \\
\hline Rho & 0.33046 & 0.13093 & & \\
\hline
\end{tabular}

Source: Primary data, one tailed test, where: Non-financial represents disclosure of non-financial information; other variables are defined in table 2

Results show that CEO non-duality has a positive significant influence on disclosure of non-financial information; that is $(\beta=0.0478, P=0.0715)$ and $(\beta=0.1178, p=0.063)$ for listed firms in South Africa and East Africa respectively. This implies that separation of roles of CEO and chairman board of directors enhances disclosure of corporate information. The findings are consistent with empirical evidence by Rouf (2010) and Olanyika (2010) which show that separation of the roles of the two officers enhance disclosure of corporate information. However, consisted with results by Khaled et al. (2012), findings from listed firms in Nigeria show that separation of roles has a negative significant influence on disclosure $(\beta=-0.893, p=0.0335)$. Findings also show that board composition has a significant and positive effect on disclosure of non-financial information; $(\beta=$ $0.0927, p=0.0325)$ and $(\beta=0.26375, p=0.0415)$ for listed firms in South Africa and East Africa respectively. This implies that a high proportion of non-executive directors on the board of directors enhance disclosure of corporate information. This is consistent with the argument that non- executive directors ensure that there is effective monitoring of company operations and cause management to disclose all the information required by the stakeholders (Nandi and Goshi, 2012). However, for listed firms in Nigeria; results show that the effect of board composition on disclosure of non-financial information is not significant.

The study further established that board size has a positive significant effect on corporate disclosure for Nigerian listed firms $(\beta=0.0163, p=0.013)$. This is consistent with Tariq, Essia and Mohammed (2019); Soliman and Ragab (2013); Ntim et al. (2012) and Samaha et al. (2012) that a large board size has a wide range of professionals with diverse financial reporting expertise which ultimately lead to a higher disclosure quality. Results from listed firms in South Africa and East Africa on the effect of board size were not significant. Results from listed firms in South Africa also reveal that Block shareholding has a negative significant effect on disclosure of non- financial information $(\beta=-0.0695, p=0.0025)$. This is consistent with Khan et al. (2012) that there is limited accountability in such companies because of few outside shareholders. Furthermore, the study established that director ownership has a negative significant effected on corporate disclosure of non-financial information $(\beta=$ - 
$0.0892, \mathrm{p}=0.0025)$. The findings are consistent with empirical evidence by Rouf (2011) and Nazli (2007) which revealed that companies where executive and non-executive directors hold a significant number of shares, disclose less governance and corporate social responsibility information to the public. The study did not establish any significant effect of block and director shareholding on disclosure of non- financial information for listed firms in Nigeria and East Africa.

\section{0: Implication and contribution of the study}

The purpose of the study was to examine the effect of corporate governance attributes on disclosure of nonfinancial information for firms listed on selected stock markets in Sub- Saharan Africa. The non-financial information includes information on strategic, governance, environmental and corporate social responsibility activities. The study concluded that separation of roles of chief executive officers from those of board chairman, board size and higher proportion of non-executive directors on the board have a positive significant effect on disclosure of both governance and corporate social responsibility information. The implication of this is that for effective monitoring of corporate operations and corporate disclosure of all available information, firms should as much as possible separate roles of chief executive officer and board chairman. Furthermore, an expanded board size provides a pool of experienced directors with diverse expertise to corporate boards although this is criticized that the decision making process is slow. In addition, findings point to the fact that; to provide effective supervision of companies' operations and enhanced disclosure, the proportion of independent non-executive directors should be increased. The study further reveals that higher proportions of block and director shareholdings negatively affects disclosure of non-financial information. That these categories of shareholders can easily access information without necessarily making public disclosures. And therefore, in companies where they hold majority shares, there's no motivation for companies to make public disclosures. This has an implication to the development of stock markets in developing economies where in order to encourage efficient operations and disclosure of public information, the proportions of block and director shareholdings should be minimized.

The study makes a contribution to literature on effectiveness of corporate governance attributes on disclosure of non-financial information specifically in Sub- Saharan Africa and developing economies in general. The effectiveness of various corporate governance attributes on corporate disclosure has been empirically tested thus, guiding the growth and operations of stock markets in these economies. The study provides guidance to stock market players and regulators on roles of chairman board of directors and chief executive officer, effectiveness of board size and composition, block and director shareholding on enhancing financial reporting and disclosure of non-financial corporate information. Provision of information is key to both potential and existing shareholders to make informed investment decisions.

\section{References}

Abdifatah Ahmed Haji, (2013),"Corporate social responsibility disclosures over time: evidence from Malaysia". Managerial Auditing Journal, 28 (7), 647 - 676.

Aboagye, O. F., Bedi, I., \& Ossei, K. T. (2012). Corporate governance and disclosure practices of Ghanaian listed companies. Journal of Accounting in Emerging Economies, 2(2), 140-161.

Adawi, M., \& Rwegasira, K. (2012). The influence of patterns of ownership structure on transparency in corporate governance: Evidence from United Arab Emirates listed companies. Journal of Transnational Management, 17 (4), 239-257.

Akhtaruddin, M., \& Hasnah, H. (2010). Board ownership, audit committees, effectiveness and corporate voluntary disclosures. Asian Review of Accounting, 18(1), 68-82.

Akhtaruddin, M., Alam, H. M., Mahmud, H., \& Yao, L. (2009). Corporate governance and voluntary disclosure in corporate annual reports of Malaysian listed firms. Journey of Applied Management Accounting Research, $7(1), 1-20$.

Arosa, B., Txomin, I., \& Amaia, M. (2010). Ownership structure and firm performance in non-listed firms: Evidence from Spain. Journal of Family Business Strategy, 1, 88-96.

Barakat, F.S.Q., Lopez Perez, M. V., \& Ariza, L. R. (2015). Corporate social responsibility disclosure determinants of listed companies in Palestine and Jordan. Journal of Management Science, 9(4), 681-702.

Barako, D.G., Hancock, P., \& Izan, H. Y. (2006). Factors influencing voluntary corporate disclosure by Kenyan Companies. Corporate Governance: An International Review, 14(2), 107-125.

Chakraborty, I. (2010). Capital structure in an emerging stock market: The case of India. Journal of Research in International Business and Finance, 24(3), 295 - 314.

Desoky, A. M., \& Mousa, G. A. (2012). Corporate governance practices: Transparency and disclosure - Evidence from Egyptian exchange. Journal of Accounting, Finance and Economics, 2(1), 49-72.

Elinda, E., \& Nazli, A. M. G. (2012). Corporate social responsibility and corporate governance in Malaysian government-linked companies, corporate governance: The International Journal of Business in Society, 12(3), 292-305. 
Elsayed, O. M., \& Hoque, Z. (2010). Perceived international environmental factors and corporate voluntary disclosure practices: An empirical study. The British Accounting Review. 42, 17-35.

Erna, L., Riska, D., and Nur, B. (2018). The effect of good corporate governance and corporate social responsibility disclosure Jakarta Islamic Index. Indonesian Journal of Business and Entrepreneurship, 4(3): 273-281.

Ezhilarasi, G., \& Kabra, K. C. (2017). The impact of corporate governance attributes on nvironmental disclosures: Evidence from India. Indian Journal of Corporate Governance, 10(1), 24-43.

Ferreira, A. L., Branco, M. C., \& Moreira, J. A. (2012). Factors influencing Intellectual capital disclosure by Portuguese companies. International Journal of Accounting and Financial Reporting, 2(2), 278-298.

Gujarati, N. D. (2003). Basic Econometrics. McGraw-Hill Higher Education. New York, $4^{\text {th }}$ edition. ISBN: 0-07233542-4

Gunawan, A. (2019). The role of corporate governance mechanism on voluntary disclosure. Jurnal Akuntansi, 28(1):127-142

Habibi, H., \& Shamsi, E. (2015). The Effect of change in auditor's opinion on timely disclosure of financial information. International Journal of Management, Accounting and Economics, 2(3), 200-209.

Htay, S. N. N., Said, R. M. \& Salman, S. A. (2013). Impact of corporate governance on disclosure quality: Empirical Evidence from listed banks in Malaysia. International Journal of Economics and Management, 7(2), 242-279.

Ibrahim, A., Habbash, M., \& Hussainey, K. (2019). Corporate governance and risk disclosure: Evidence from Saudi Arabia. International Journal of Accounting, Auditing and Performance Evaluation, 15(1), 89-111.

Jensen, M., \& Meckling, W. (1976). Theory of the Firm: Managerial behaviour, agency costs and ownership structure. Journal of Financial Economics, 3, 305-360.

Jing, L., Richard, P., \& Roszaini, H. (2008). Intellectual capital disclosure and corporate governance structure in UK firms. Journal of Accounting and Business Research, 38(2),137-159.

Jizi, M. I., Salama, A., Dixon, R., \& Stratling, R. (2014). Corporate governance and corporate social responsibility disclosure: Evidence from the US banking sector. Journal of Business Ethics, 125, 601-615.

Khalid, A. (2006). The association between firm specific characteristics and disclosure. The case of Saudi Arabia. Managerial Auditing Journal, 21(5), 476-496.

Khan, A., Muttakin, M. B., \& Siddiqui, J. (2012). Corporate governance and corporate social responsibility disclosures: Evidence from an emergency economy. Journal of Business Ethics, 114, 207-223.

Laivi, L., (2009). Association between ownership structure and public announcement's disclosure. CorporateGovernance: An International Review, 17(1), 13-34.

Marta de la Cuesta Carmen Valor, (2013),"Evaluation of the environmental, social and governance information disclosed by Spanish listed companies". Social Responsibility Journal, 9(2), 220 - 240.

Meser, M., Veith, S., \& Zimmermann, J. (2015). Disclosure, enforcement, and capital market properties: A longitudinal analysis for Germany. Schmalenbach Business Review, 67(1), 254-285.

Mukhtaruddin., Saftiana, Y., \& Dwikatama, P.A. (2018). Firm's characteristics, corporate governance quality and corporate social responsibility disclosure. Sriwijana International Journal of Dynamic Economics and Business, 2(3), 193-212.

Nandi, S., and Ghosh, S.K. (2012). Corporate governance attributes, firm characteristics and level of corporate disclosure: Evidence from Indian listed firms. Growing Science limited, 2, 45-58.

Naseem, M.A., Riaz, S., Rehman, R. U., Ikram, A., \& Malik, F. (2017). Impact of board characteristics on corporate social responsibility disclosure. The Journal of Applied Business Research, 33(4), 801-810.

Nauman, Z. (2013). Effects of duality, board size and board composition on corporate governance disclosure in Pakistan. International SAMANM Journal of Finance and Accounting, 1(3), 1-16.

Nazli, A.M.G. (2007). Ownership structure and corporate social responsibility disclosure: Some Malaysian evidence. Journal of corporate governance, 7(3), 251-266.

Ntim, G. C., Kwaku, K. P., Danbolt, J. (2012). Voluntary corporate governance disclosures by Post-Apartheid South African Corporations. Journal of Applied Accounting Research, 13(2), 122-144.

Nurul, N. J., \& Sherliza, P. N. (2011). An Investigation on the audit committees 'effectiveness: The case for Government-Linked companies (GLCs) in Malaysia. Gadjah Mada International Journal of Business, 13(3), 287-305.

Odoemelam, N., \& Okafor, R. G. (2018). The influence of corporate governance on environmental disclosure of listed non-financial firms in Nigeria. Indonesian Journal of Sustainability Accounting and Management, 2(1), 25-49.

Olanyika, M. U. (2010). The impact of board structure on corporate financial performance in Nigeria. International Journal of Business and Management, 5(10), 155-166.

Oluwaremi, F. (2014). The level of financial information disclosure and corporate attributes in developing economy. European Journal of Business and Management, 6(3), 176-188.

Omran, M., \& Abdelrazik, M. (2013). The association between corporate governance and corporate disclosure: A 
critical review. Journal of Public Administration and Governance, 3(3), 94-107.

Parves, M., \& Abdullah, A.M. (2011). Corporate social disclosure during the global financial crisis. International Journal of Economics and Finance, 3(6), 174-187.

Patelli, L., \& Prencipe, A. (2007). The relationship between voluntary disclosure and independent directors in the presence of a dominant shareholder. European Accounting Review, 16(1), 5-33.

Poh, L. H., \& Grantley, T. (2013). Corporate governance and different types of voluntary disclosure: Evidence from Malaysian listed firms. Pacific Accounting Review, 25(1), 4-29.

Roshima, S., Yeserrie, H. Z., \& Hasnah, H. (2009). The relationship between corporate social responsibility disclosure and corporate governance characteristics in Malaysian public listed companies. Social responsibility Journal, 5(2), 212-226.

Rouf, A. (2011). Corporate characteristics, governance attributes and the extent of voluntary disclosure in Bangladesh. African Journal of Business management, 5(19), 7836 - 7845.

Samaha, K., Dahawy, K., Hussaney, K., and Stapleton, P. (2012). The extent of corporate governance disclosure and its determinants in a developing market: The case of Egypt. Journal of Advances in International Accounting, 28, $168-178$.

Sartawi, S. I., Hindawi, R. M., Bsoul, R., \& Ali, J. A. (2014). Board composition, firm characteristics and voluntary disclosure: The case of Jordan firms listed on Amman Stock Exchange. International Business Research, 7(6), 67-82.

Shin, H. D., Lee, N. R., \& Park, J. H. (2015). Differential effects of strong corporate governance on both professional and voluntary corporate social responsibility activities of the firm. Journal of Emerging Markets Finance and Trade, 51(4), 2-10.

Soliman, M. M., \& Ragab, A. A. (2013). Board of directors' attributes and earnings management: Evidence from Egypt. Proceedings of the $6^{\text {th }}$ International Business and Social Sciences Research Conference 3-4 January, 2013, Dubai, UAE, ISBN: 978-1-922069-18-4. Retrieved from https://www.wbiconpro.com/335 Moustafa.

Stefanescu, C. A. (2013). How do boards of directors affect corporate governance disclosure? The case of banking system. The Romanian Economic Journal, Year XVI (47), 127-146.

Sweeney, L., \& Coughlan, J. (2008). Do different industries report corporate social responsibility differently? An investigation through the lens of stakeholder theory. Journal of marketing communications, 14(2), 113-124.

Tariq, T. Y. A., Essia, R. A., and Mohammed, M. (2019). Effect of board size and duality on Corporate Social Responsibility: What has improved in corporate governance in Asia? Journal of Accounting Science, 3(2), $121-135$

Ujunwa, A. (2012). Board characteristics and the financial performance of Nigerian Quoted firms. Corporate governance, 12(5), 656-674.

Won,S. K., Alan, K., \& Sue, W. (2011). The effectiveness of audit committees for low- andmid- cap firms. Managerial Auditing Journal, 26(7), 623-650. 